\title{
Growth Profile and Toxigenicity of Bacillus cereus in Ready-to-eat Food Products of Animal Origin
}

\author{
Mi-Hwa Oh${ }^{1}$, Jun-Sang Ham ${ }^{1}$, Kuk-Hwan Seol ${ }^{1}$, Aera Jang ${ }^{1}$, Seung-Gyu Lee ${ }^{1}$, Jong-Moon Lee ${ }^{1}$, \\ Beom-Young Park', Eun-Sil Kang ${ }^{2}$, Ki-Sung Kwon, and In-Gyun Hwang* \\ National Institute of Food and Drug Safety Evaluation, Korea Food and Drug Administration, \\ Cheongwon 363-951, Korea \\ ${ }^{I}$ National Institute of Animal Science, Rural Development Administration, Suwon 441-744, Korea \\ ${ }^{2}$ Ildongfoodis R\&D Center, Chuncheon 200-881, Korea
}

\begin{abstract}
The growth profile of Bacillus cereus in ready-to-eat (RTE) food products of animal origin was examined under different temperature and incubation conditions. In sandwiches and Kimbab, B. cereus did not grow or exhibited only minimal growth at 4 and $10^{\circ} \mathrm{C}$, but it grew rapidly at ambient temperature. In sandwiches, B. cereus did not grow efficiently at $25^{\circ} \mathrm{C}$, however, in ham, the main ingredient of sandwiches, $B$. cereus growth was observed at the same temperature, with bacterial levels reaching $7.94 \mathrm{Log} \mathrm{CFU} / \mathrm{g}$ after incubation for $24 \mathrm{~h}$ at $25^{\circ} \mathrm{C}$. Toxigenicity of $B$. cereus was observed only at temperatures above $25^{\circ} \mathrm{C}$. In Kimbab, B. cereus produced toxin after $9 \mathrm{~h}$ at $30^{\circ} \mathrm{C}$ and after $12 \mathrm{~h}$ at $25^{\circ} \mathrm{C}$. Ingredients of sandwiches and Kimbab were collected from 3 different Korean food-processing companies to investigate the source of contamination by $B$. cereus. Among the 13 tested food items, 6 items including ham were found to be contaminated with $B$. cereus. Of these ingredients, $B$. cereus isolates from 3 items produced enterotoxins. None of these isolates harbored the emetic toxin-producing gene. The findings of the present study can be used for risk assessments of food products, including ham and cheese, contaminated with B. cereus.
\end{abstract}

Key words: Bacillus cereus, growth profile, toxigenicity, enterotoxin, emetic toxin

\section{Introduction}

Although substantial progress has been achieved in the food industry and in food safety management, the incidence of food poisoning remains a major problem in this industry in terms of social and economic losses. Animalderived food products have been the primary cause of food poisoning outbreaks in Korea for the last 11 years (Bahk, 2009), and recently, in line with the increased consumption of ready-to-eat (RTE) foods, the incidence of food poisoning related to these foods has increased (Bahk et al., 2007). Kimbab and sandwiches are the most common RTE foods in Korea, and ham and cheese are their major ingredients.

Bacillus cereus is a soil-borne microorganism that is widely distributed in the natural environment (soil, water,

\footnotetext{
*Corresponding author: In-Gyun Hwang, Food Microbiology Division, National Institute of Food and Drug Safety Evaluation, Korea Food and Drug Administration, Cheongwon 363-951, Korea. Tel: 82-43-719-4301, Fax: 82-43-719-4315, E-mail: inghwang@kfda.go.kr
}

and dust); and therefore, is also found in foodstuffs of vegetable and animal origin. Many investigators have reported that $B$. cereus is a contaminant of not only raw meat (Johnson, 1984; Nel et al., 2004), but also processed meat products (Sooltan et al., 1987; Nortjé et al., 1999). Psychrotrophic strains of $B$. cereus can also contaminate refrigerated foods, such as RTE foods. Some strains of $B$. cereus can grow at temperatures below $10^{\circ} \mathrm{C}$. These strains have mainly been isolated from dairy products (Andersen Borge et al., 2001; van Netten et al., 1990).

$B$. cereus is difficult to eliminate from foodstuffs and food-processing systems because it forms spores that are ubiquitous and highly resistant to adverse conditions such as heat, dehydration, and other physical stresses (Andersson, 1995; Doan and Davidson, 1999; Larsen and Jørgensen, 1999). B. cereus is associated with 2 distinct types of gastrointestinal disorders: diarrheal and emetic syndromes (Beattie and Williams, 2000; Schoeni and Wong, 2005). The first and better understood is the diarrheal syndrome caused by $B$. cereus enterotoxins; this syndrome is associated with diarrhea and abdominal pain 
occurring 8-16 $\mathrm{h}$ after the ingestion of contaminated foods. The emetic syndrome is caused by the emetic toxin of $B$. cereus and is characterized by nausea and vomiting occurring 1-5 $\mathrm{h}$ after the ingestion of contaminated foods.

In this study, we examined the growth patterns and toxigenicity of $B$. cereus in foodstuffs of animal origin, such as ham and cheese, in RTE sandwiches and Kimbab, and analyzed these ingredients to identify the major sources of $B$. cereus contamination and thereby improve the management of $B$. cereus contamination of RTE foods.

\section{Materials and Methods}

\section{B. cereus strains}

To choose the strain of $B$. cereus used for generating growth pattern and analyzing toxin production according to differences in temperature and growth matrix, the toxin production of five $B$. cereus reference strains (ATCC 11778, KCTC 1092, KCTC 1094, KCTC 1013, and KFRI 181) was tested. The diarrhoeal type B. cereus enterotoxin test kit (RPLA kit; Oxoid, England) was used to examine toxin production according to the manufacturer's instructions as described in Fig. 1. Among the five strains tested, B. cereus KTCT 1013 was selected for use in the remainder of the experiments.
Food materials for the growth profile of $B$. cereus

After testing a variety brands of sandwich and Kimbab samples, those found to be uncontaminated with viable microorganisms were chosen as matrices for generating growth patterns for $B$. cereus. Chosen sandwiches and Kimbab not inoculated with bacteria were served as samples for each experiment.

\section{Growth profile of $B$. cereus}

$B$. cereus KTCT 1013 was grown in tryptone soya broth (Oxoid) for $20 \mathrm{~h}$ prior to inoculation. B. cereus $\left(1-2 \times 10^{3}\right.$ $\mathrm{CFU} / \mathrm{g})$ was used to inoculate a slice of Kimbab $(20 \mathrm{~g})$ and it was left for $20 \mathrm{~min}$ to be absorbed. For the sandwiches and sandwich ingredients (ham and cheese), 1-2x $10^{3} \mathrm{CFU} / \mathrm{g}$ of $B$. cereus was inoculated onto $20 \mathrm{~g}$ of sandwich slice or ingredients, which were left for $20 \mathrm{~min}$ to be absorbed. The inoculated samples were homogenized with $180 \mathrm{~mL}$ of sterilized saline $(0.85 \%)$ by stomaching (Stomacher 400, UK) for $2 \mathrm{~min}$. Then, the samples were serially diluted and inoculated onto mannitol-egg yolkpolymyxin agar (Oxoid), and incubated for 24-48 h at $35^{\circ} \mathrm{C}$. Following incubation, pink colonies surrounded by a zone of precipitation were counted and selected for identification by BBL-crystal Gram-positive (GP; Becton Dickinson, USA) analysis and 16S rDNA sequencing.

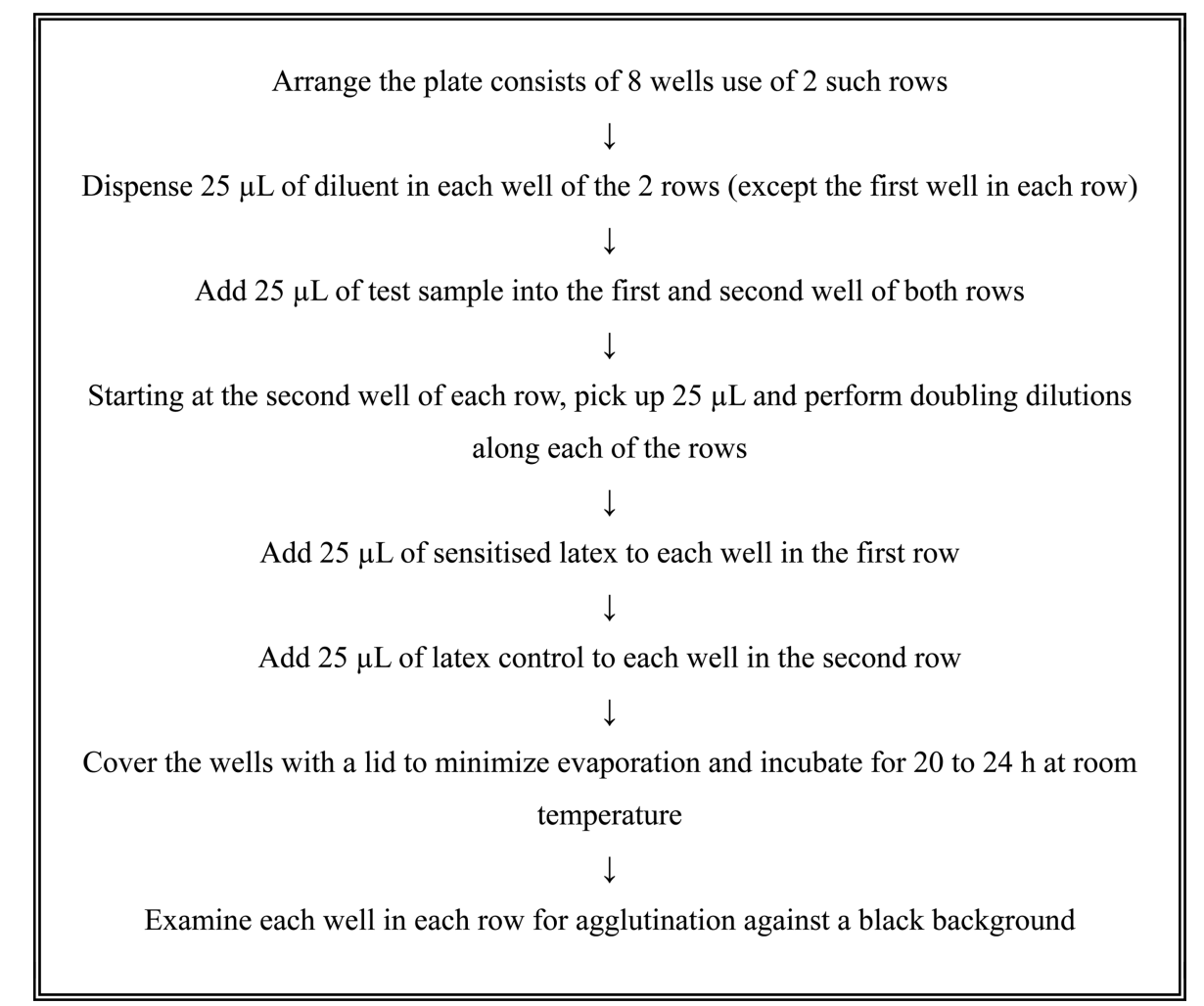

Fig. 1. RPLA procedure for detection of diarrhoeal toxin. 
The growth and toxin production of $B$. cereus in Kimbab and BHI broth (Oxoid) was analyzed at 4, 10, 25, and $30^{\circ} \mathrm{C}$. Incubation times were $0,3,6,9,12,18$, and 24 h. For sandwiches and sandwich ingredients (ham and cheese), the growth was analyzed at 10 and $25^{\circ} \mathrm{C}$ for 0,3 , $6,9,12,18$, and $24 \mathrm{~h}$. At each time point, the number of viable cells was counted and toxin production was analyzed.

\section{Examination of $B$. cereus contamination in RTE ingredients}

To examine contamination sources of ingredients, three different food processing companies in Korea (A, B, and C) were selected and collected ingredients used for Kimbab (rice rolled in dried laver) and sandwiches. The 13 ingredients $(\mathrm{n}=37)$ of Kimbab and sandwiches are including ham, cheese (for both Kimbab and sandwiches), dried laver, steamed rice, carrot, pickled radish, cucumber, tuna, bread, lettuce, dried gourd, salad and tomato. The level of $B$. cereus contamination of each ingredient was determined as follow; $20 \mathrm{~g}$ of samples were homogenated with $180 \mathrm{~mL}$ of sterilized sarline $(0.85 \%)$ for $2 \mathrm{~min}$, then the samples were serially diluted and inoculated onto mannitol-egg yolk-polymyxin agar (Oxoid), and incubated for $24-48 \mathrm{~h}$ at $35^{\circ} \mathrm{C}$. Following incubation, pink colonies surrounded by a zone of precipitation were counted and selected for identification by BBL-crystal Gram-positive (GP; Becton Dickinson, USA) analysis and $16 \mathrm{~S}$ rDNA sequencing.

\section{Confirmation of $B$. cereus isolated from food ingre- dients}

BBL-Crystal GP (Becton Dickinson, USA) confirmation of $B$. cereus isolated from food ingredients was performed according to the manufacturer's instructions. For sequencing, DNA of Bacillus strains was isolated using the DNeasy ${ }^{\circledR}$ Blood and Tissue kit (Qiagen, USA) and PCR amplification was carried out as described by Nübel et al. (1996) and Garbeva et al. (2001) using the universal primers 968F (5'-AACGCGAAGAACCTTAC-3'; Eubacteria V6; Heuer et al., 1999) and 1401R (5'-CGGTGTGTACAAGACCC-3'; Eubacteria V9; Nübel et al., 1996). PCR amplification was performed in a reaction volume of $50 \mu \mathrm{L}$ containing: $1 \times \mathrm{PCR}$ buffer, $0.2 \mu \mathrm{M}$ of each primer, $200 \mu \mathrm{M}$ of each dNTP, $1.5 \mathrm{mM} \mathrm{MgCl} \mathrm{M}_{2}, 1.25$ $\mathrm{U}$ of Taq DNA polymerase and $10 \mathrm{ng}$ of extracted DNA. The PCR was performed using a DNA thermal cycler (Gene Amp PCR system 9700) (Applied Biosystems, USA). The temperature cycles comprised initial denatur- ation at $94^{\circ} \mathrm{C}$ for $2 \mathrm{~min}, 10$ cycles at $94^{\circ} \mathrm{C}$ for $30 \mathrm{~s}, 50^{\circ} \mathrm{C}$ for $30 \mathrm{~s}$, and $72^{\circ} \mathrm{C}$ for $45 \mathrm{~s}$, followed by 20 times the same cycle with each successive cycle at $5 \mathrm{~s}$ longer elongation time. The final elongation was conducted for 10 min at $72^{\circ} \mathrm{C}$. PCR amplicons were visualised by gel electrophoresis and PCR products of interest were used for sequence analysis. Sequencing of $B$. cereus isolates was carried out with the ABI PRISM ${ }^{\circledR}$ BigDye $^{\mathrm{TM}}$ Terminator v3.1 Cycle Sequencing Kit (Applied Biosystems, USA) and submitted to Bioneer, Inc. (Korea) for analysis.

\section{Toxigenicity of $B$. cereus isolates}

The samples were prepared by inoculating a loopful of biomass from a $24 \mathrm{~h}$ culture on tryptone soya agar (Oxoid) into $10 \mathrm{~mL}$ of brain heart infusion (BHI, Oxoid) broth, incubated for $16-18 \mathrm{~h}$ at $35-37^{\circ} \mathrm{C}$. Analysis of enterotoxin production was conducted using the RPLA kit according to the manufacturer's instructions as described in Fig. 1. PCR was performed to detect the emetic toxin gene. The primer set and the PCR conditions for detection of the emetic toxin gene were as described by Toh et al. (2004). The PCR primers used were BE F (5'ACTTAGATGATGCAAGACTG-3') and BE R (5'-TTCATAGGATTGACGAATTTT-3'). PCR amplification was performed in a reaction volume of $30 \mu \mathrm{L}$ containing $3 \mu \mathrm{L}$ $\mathrm{MgCl}_{2}, 3 \mu \mathrm{L} 10 \times$ buffer, $2 \mu \mathrm{L}$ dNTPs, $0.1 \mu \mathrm{L}$ Taq polymerase, $1 \mu \mathrm{L}$ each of the forward and reverse primer in $19 \mu \mathrm{L}$ Milli-Q water, and $1 \mu \mathrm{L}$ of DNA was included in the reaction volume. The amplification was performed using 30 cycles, each consisting of $10 \mathrm{~s}$ at $94^{\circ} \mathrm{C}, 20 \mathrm{~s}$ at $50^{\circ} \mathrm{C}$, and $80 \mathrm{~s}$ at $72^{\circ} \mathrm{C}$, with a final extension step at $72^{\circ} \mathrm{C}$ for $7 \mathrm{~min}$. PCR products were analysed by gel electrophoresis in $1 \%(\mathrm{w} / \mathrm{v})$ agarose gels in TBE buffer and visualized by staining with ethidium bromide.

\section{Statistical analysis}

All experiments for growth profile of $B$. cereus were replicated three times. Statistical analysis (ANOVA) of data was performed using the SigmaStat 2.03 program (SigmaAldrich, USA). Duncan's multiple range test was used to analyze the statistical significance of the means.

\section{Results}

\section{Analysis of $B$. cereus growth profile and toxigenic- ity in RTE foods}

Among the strains tested, such as B. cereus ATCC 11778, KCTC 1092, KCTC 1094, KCTC 1013 and KFRI 181, B. cereus KTCT 1013 showed the highest toxin pro- 
duction (data not shown) and was selected for inoculation.

As illustrated in Fig. 2, B. cereus grew only slightly in $K i m b a b$ at 4 and $10^{\circ} \mathrm{C}$. The bacteria was inoculated at $3.11 \mathrm{Log} C F U / g$ and after $24 \mathrm{~h}$ at 4 or $10^{\circ} \mathrm{C}$, the bacterial counts were 3.40 and $3.66 \mathrm{Log} \mathrm{CFU} / \mathrm{g}$, respectively. There were significant differences in the bacterial counts between 0 and $24 \mathrm{~h}$ at 4 and $10^{\circ} \mathrm{C}(p<0.05)$. When grown at higher temperatures, number of $B$. cereus increased dramatically to $5.80 \mathrm{Log} \mathrm{CFU} / \mathrm{g}$ at $25^{\circ} \mathrm{C}$ and to $6.91 \mathrm{Log}$ $\mathrm{CFU} / \mathrm{g}$ at $30^{\circ} \mathrm{C}$ after $24 \mathrm{~h}$ (Fig. 2).

No toxin production was detectable in the bacteria grown at 4 and $10^{\circ} \mathrm{C}$; the samples were negative for toxin production at all stages tested until $24 \mathrm{~h}$. However, at 25 and $30^{\circ} \mathrm{C}$, all samples started to produce toxin after 12 and $9 \mathrm{~h}$, respectively (Fig. 2). In comparison, when $B$. cereus was grown in $\mathrm{BHI}$ broth, toxin production was similar to that in Kimbab at 4, 10, and $25^{\circ} \mathrm{C}$. However, in $\mathrm{BHI}$ at $30^{\circ} \mathrm{C}$, B. cereus began producing toxin after $12 \mathrm{~h}$, which was later than in Kimbab (data not shown).

$B$. cereus did not grow rapidly in sandwiches at $25^{\circ} \mathrm{C}$. As illustrated in Fig. 3, there was no significant growth of $B$. cereus in the sandwich during $24 \mathrm{~h}$ of storage at $10^{\circ} \mathrm{C}$ $(p>0.05)$, whereas there was slight growth in Kimbab under these same conditions. Even though the growth rate of $B$. cereus in sandwiches was significantly different at hour-0 versus hour- 12 at $25^{\circ} \mathrm{C}(p<0.05)$, the number of $B$. cereus increased only from $3.80 \mathrm{Log} \mathrm{CFU} / \mathrm{g}$ (inoculation concentration) to $3.98 \mathrm{Log} \mathrm{CFU} / \mathrm{g}$.

Therefore, to determine the ingredients that posed a greater risk for bacterial contamination, the growth patterns of $B$. cereus in the most frequently used ingredients for sandwiches and Kimbab such as ham and cheese were examined (Fig. 4). In the ham, there was no change in

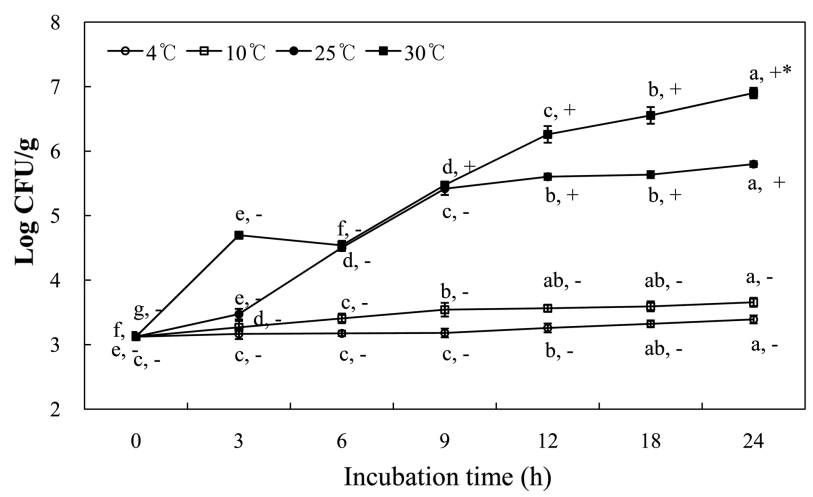

Fig. 2. Growth patterns of $B$. cereus at various temperatures in Kimbab. ${ }^{* a-g}$ In same sample with different superscripts are significantly different $(p<0.05)$. + or - means the toxin-production of $B$. cereus.

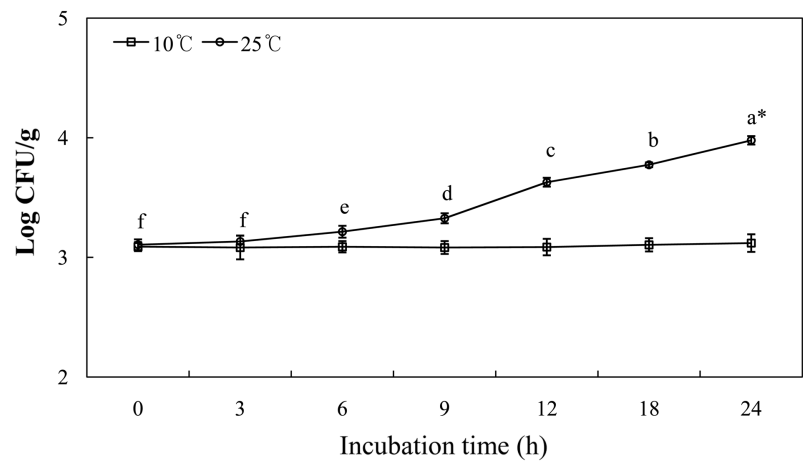

Fig. 3. Growth patterns of $B$. cereus at 10 and $25^{\circ} \mathrm{C}$ in sandwiches. ${ }^{* a-f}$ In same sample with different superscripts are significantly different $(p<0.05)$.

number of $B$. cereus after the inoculation of $3.32 \mathrm{Log}$ $\mathrm{CFU} / \mathrm{g}$ at $10^{\circ} \mathrm{C}$. However, at $25^{\circ} \mathrm{C}$, the growth rate of $B$. cereus increased rapidly between 6 and $9 \mathrm{~h}$ and the number of B. cereus increased from 3.72 Log CFU/g to 4.08 Log CFU/g, ultimately reaching $7.94 \mathrm{Log}$ CFU/g at $24 \mathrm{~h}$ representing the higher level of growth of $B$. cereus than cheese (Fig. 4). In contrast, B. cereus did not grow in the cheese regardless of incubation temperature (Fig. 4).

In whole sandwich samples, $B$. cereus grew only to the level of $3 \mathrm{Log} \mathrm{CFU} / \mathrm{g}$ and did not produce enterotoxin in any stage, thus it was not possible to evaluate toxin pro-
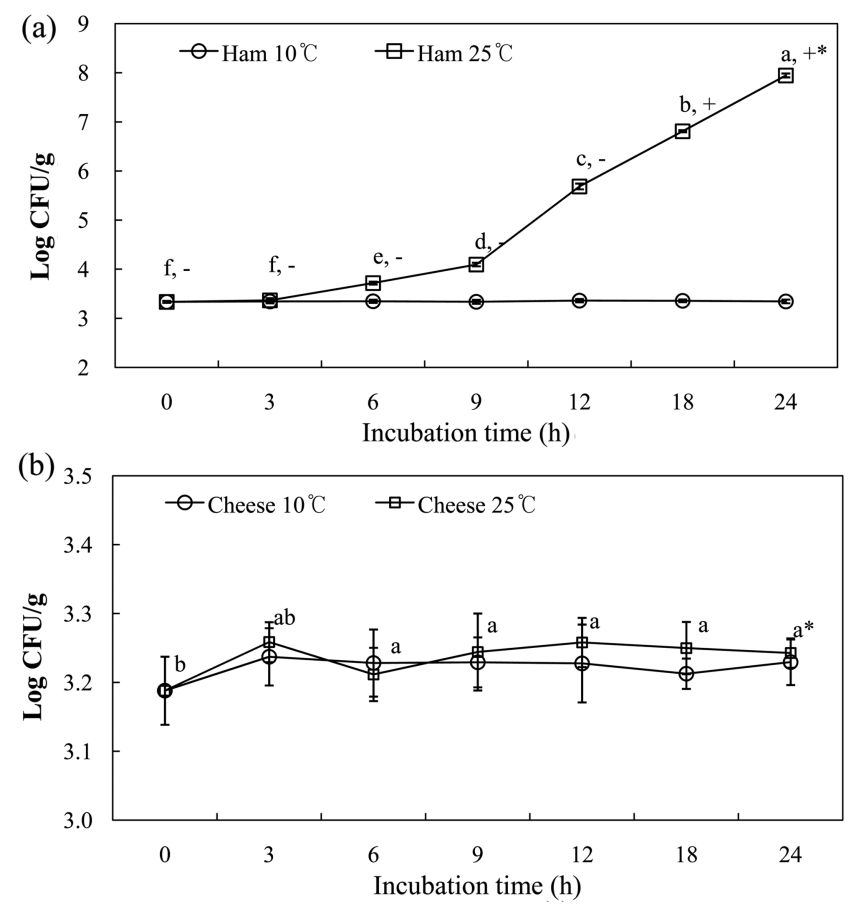

Fig. 4. Growth patterns of $B$. cereus at 10 and $25^{\circ} \mathrm{C}$ in ham (a) and cheese (b). ${ }^{* a-f}$ In same sample with different superscripts are significantly different $(p<0.05)$. + or means the toxin-production of $B$. cereus. 
duction according to the growth of $B$. cereus in sandwiches (Fig. 3). Therefore, we evaluated toxin production in ham, which supported the greatest $B$. cereus growth of all sandwich ingredients (Fig. 4a). There was no enterotoxin production detected when the samples were grown at 4 or $10^{\circ} \mathrm{C}$ for $24 \mathrm{~h}$. However, at 25 and $30^{\circ} \mathrm{C}$, all samples started to produce toxin by $18 \mathrm{~h}$.

\section{B. cereus contamination in food ingredients of RTE foods}

To determine the sources of contamination of ingredients, we visited three food companies and collected 13 ingredients $(\mathrm{n}=37)$ of Kimbab and sandwiches and evaluated $B$. cereus contamination in those samples. Isolates from samples were confirmed as $B$. cereus-positive after BBL-crystal GP analysis and sequencing showed 99\% similarity to $B$ cereus (data not shown). B. cereus was detected in ham and bread used for sandwiches and in cucumber, carrot, and laver for Kimbab (Table 1).

\section{Toxigenicity of $B$. cereus isolated from food ingre- dients of RTE foods}

The results of enterotoxin production evaluation and screening for the presence of the emetic toxin-producing gene in the Bacillus strains isolated from food ingredients are shown in Table 2. B. cereus isolates from ham didn't produce enterotoxin. However, all B. cereus isolates from cucumber collected from two different companies and one isolates from bread produced enterotoxin. There is no

Table 1. Screening of B. cereus existence from Kimbab and sandwich ingredients

\begin{tabular}{|c|c|c|c|c|}
\hline \multirow{2}{*}{\multicolumn{2}{|c|}{ Food ingredient }} & \multicolumn{3}{|c|}{ Contamination level (Log CFU/g) } \\
\hline & & Company A & Company B & Company $\mathrm{C}$ \\
\hline \multirow{8}{*}{ Kimbab } & Steamed rice & ND & ND & 2.78 \\
\hline & Ham & ND & - & $\mathrm{ND}^{1}$ \\
\hline & Cheese & - & - & ND \\
\hline & Dried laver & ND & 3.48 & $<10^{2}$ \\
\hline & Pickled radish & ND & ND & ND \\
\hline & Cucumber & $<2$ & ND & $<10^{2}$ \\
\hline & Carrot & ND & 2.30 & - \\
\hline & Dried gourd & ND & ND & - \\
\hline \multirow{7}{*}{ Sandwich } & Bread & $<2$ & ND & $<2$ \\
\hline & Ham & ND & $<2$ & ND \\
\hline & Cheese & ND & ND & - \\
\hline & Salad & ND & ND & ND \\
\hline & Lettuce & ND & ND & ND \\
\hline & Tomato & ND & - & ND \\
\hline & Tuna & - & ND & ND \\
\hline
\end{tabular}

${ }^{1} \mathrm{ND}$, not detected; -, not tested
Table 2. Toxigenicity of $B$. cereus isolated from food ingredients

\begin{tabular}{|c|c|c|c|c|}
\hline \multicolumn{2}{|c|}{ Food ingredient } & \multirow{2}{*}{$\frac{\text { Company }}{\text { C }}$} & \multicolumn{2}{|c|}{$\begin{array}{l}\text { Enterotoxin Emetic toxin } \\
\text { production }^{1} \text { gene }\end{array}$} \\
\hline \multirow{6}{*}{ Kimbab } & Rice & & - & - \\
\hline & \multirow{2}{*}{ Dried laver } & B & + & - \\
\hline & & $\mathrm{C}$ & - & - \\
\hline & \multirow{2}{*}{ Cucumber } & A & + & - \\
\hline & & $\mathrm{C}$ & + & - \\
\hline & Carrot & B & - & - \\
\hline \multirow{3}{*}{ Sandwich } & \multirow{2}{*}{ Bread } & A & - & - \\
\hline & & $\mathrm{C}$ & + & - \\
\hline & Ham & B & - & - \\
\hline
\end{tabular}

${ }^{1_{+}, \text {Positive results; -, negative results }}$

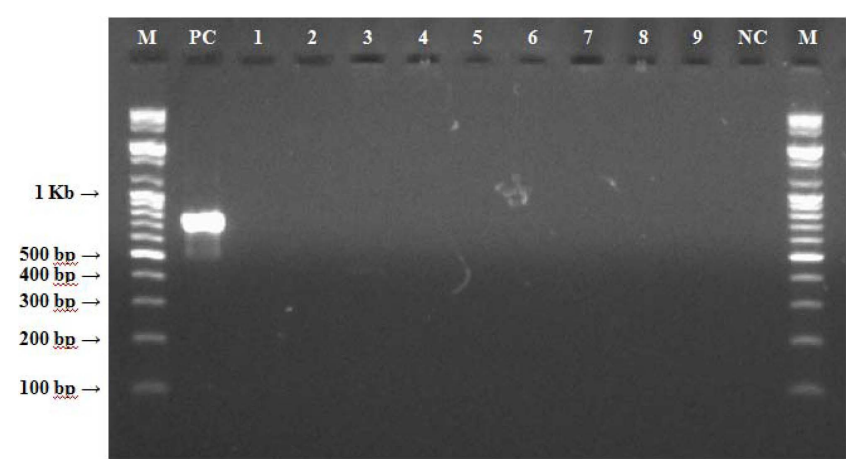

Fig. 5. Electrophoretic analysis of $B$. cereus emetic toxin gene. M, DNA markers; PC, positive control (B. cereus F4810/72); 1-6, B. cereus isolated from food ingredients of Kimbab (1, rice from company C; 2, dried laver from company B; 3 , dried laver from company $\mathrm{C} ; 4$, cucumber from company $\mathrm{A} ; 5$, cucumber from company $\mathrm{C} ; 6$, carrot from company B); 7-9, B. cereus isolated from food ingredients of sandwich $(7$, bread from company A; 8 , bread from company $\mathrm{C}$; 9 , ham from company B).

commercially available kit that screens for the presence of emetic toxin. Therefore, PCR amplification was used to detect the emetic toxin-producing gene; however, none of isolates was found to harbor this gene (Fig. 5).

\section{Discussion}

We examined the growth profile, contamination sources, and toxigenicity of $B$. cereus from ham and cheese in RTE sandwiches and Kimbab in order to identify control point to minimize $B$. cereus contamination and improve food safety management. Because of the ubiquitous nature of this organism, B. cereus can contaminate raw meat exposed to sources such as soil, hide, equipment, and personnel (Nel et al., 2004). Further, meat products containing additives such as spices, seasonings, proteins, 
starch, and colorants are more likely to be exposed to $B$. cereus because these additives have also been shown to be contaminated with B. cereus (Shinagawa et al., 1988).

In this study, we identified 2 main control points for preventing food poisoning by $B$. cereus contamination of RTE sandwiches and Kimbab. The first point of control is the storage and delivery temperature of foods, which must be rigorously maintained. We found that if the storage temperature is maintained below $10^{\circ} \mathrm{C}, B$. cereus does not grow efficiently, whereas it grows rapidly at temperatures above $25^{\circ} \mathrm{C}$ (Fig. 2 and Fig. 4a). Only 1 company among the 3 that we visited used a cold system for the entire Kimbab and sandwich preparation process. The second point of control is the initial pathogen contamination level. Because B. cereus can survive at $4^{\circ} \mathrm{C}$, the bacteria can begin to multiply if the storage conditions are changed to those more conducive to its growth. In sandwiches, the growth rate of $B$. cereus was very slow at $25^{\circ} \mathrm{C}$ (Fig. 3), in contrast to its growth rate in Kimbab (Fig. 2). However, at $25^{\circ} \mathrm{C}, B$. cereus grows efficiently in ham, one of the main ingredients of sandwiches (Fig. $4 \mathrm{a}$ ). Therefore, it is important to control the initial contamination levels of the ingredients used to prepare RTE sandwiches and Kimbab.

Our data showed that the ingredients of sandwiches and $K i m b a b$, including ham, steamed rice, bread, dried laver, cucumbers, and carrots, were contaminated with $B$. cereus. In food poisoning, the infective dose of diarrheal B. cereus ranges from 4 to $11 \mathrm{Log} \mathrm{CFU} / \mathrm{g}$ (or $\mathrm{mL}$; Granum and Lund, 1997), and in emetic food poisoning, the infective dose of $B$. cereus ranges from 3 to $10 \mathrm{Log} C F U / g$ (or $\mathrm{mL}$; Lund, 1990). It is generally thought that any food product with a $B$. cereus concentration exceeding 4 to 5 Log cells or spores/g (or $\mathrm{mL}$ ) is unsafe for consumption (Beattie and Williams, 2000; Granum, 2002), although foods with $B$. cereus concentrations higher than these values have been consumed without incident (Häggblom et al., 2002; Notermans and Batt, 1998). Therefore, even though none of sample was contaminated at a level higher than $4 \mathrm{Log} \mathrm{CFU} / \mathrm{g}$, the products cannot be described as safe. If the storage temperature is not properly controlled, $B$. cereus can multiply and produce toxins.

The toxin-producing strains of $B$. cereus must be managed carefully because $B$. cereus can produce emetic toxin and 5 types of diarrheal toxins (enterotoxins; Granum, 2002). There are 2 commercial immunoassay kits available for detecting enterotoxins. The test kit for enterotoxins produced by diarrheal type $B$. cereus (RPLA kit; Oxoid) is specific for the $\mathrm{HblC}\left(\mathrm{L}_{2}\right)$ component, whereas the Bacillus Diarrhoeal Enterotoxin Visual Immunoassay kit (BDE kit; Tecra) detects mainly the NheA (45-kDa) protein (Granum and Lund, 1997). We used the RPLA kit in this study because $\mathrm{Hbl}$ was suggested to be a primary virulence factor in B. cereus diarrhea (Beecher et al., 1995). We found that enterotoxin production by $B$. cereus inoculated into Kimbab was faster than that in ham at $25^{\circ} \mathrm{C}$, indicating that differences in the matrix can affect toxin production (Fig. 2 and Fig. 4a). However, toxin production may not be correlated to the number of cells. In our study, the $B$. cereus cell count was higher in ham (7 Log CFU/g after incubation for $12 \mathrm{~h}$ at $25^{\circ} \mathrm{C}$ and $30^{\circ} \mathrm{C}$ ) than in Kimbab ( $\sim 6 \mathrm{Log} \mathrm{CFU} / \mathrm{g}$ at same temperature) (Fig. 2 and Fig. 4a). However, toxin production was faster in Kimbab (after $12 \mathrm{~h}$ at $25^{\circ} \mathrm{C}$ ) than in ham (after 18 $\mathrm{h}$ at $25^{\circ} \mathrm{C}$ ) (Fig. 2 and Fig. $4 \mathrm{a}$ ). Therefore, we concluded that toxin production is related more to the culture medium and temperature than to the cell number.

The results generated from this systematic comparison of $B$. cereus growth and toxin production in ham and cheese in sandwiches and Kimbab according to storage temperature and time. It was found that ham is important ingredient in the respect of food safety because it supports faster growth of $B$. cereus than that in Kimbab. The growth profiles of $B$. cereus in ham and chesses, and the evaluation of RTE ingredients as sources of contamination can be used to establish risk assessments for bacilli.

\section{References}

1. Andersson, A. (1995) Bacillus cereus, strategy for survival a literature review. SIK report No. 612, Gothenburg, Sweden.

2. Anderson Borge, G. I., Skeie, M., Sørhaug, T., Langsrud, T., and Granum, P. E. (2001) Growth and toxin profiles of Bacillus cereus isolated from different food sources. Int. J. Food Microbiol. 69, 237-246.

3. Bahk, G. J. (2009) Determining of Risk Ranking for Processed Foods in Korea. J. Food Hyg. Safety 24, 200-203.

4. Bahk, G. J., Todd, E. C. D., Hong, C. H., Oh, D. H., and Ha, S. D. (2007) Exposure assessment for Bacillus cereus in ready-to-eat Kimbab selling at stores. Food Control 18, 682688

5. Beattie, S. H. and Williams, A. G. (2000) Detection of toxins. In: Encyclopedia of food microbiology. Robinson, R. K., Batt, C. A., Patel, P. D. (eds) Academic Press, A Harcourt Science and Technology Company, London, pp. 141-148.

6. Beecher, D. J., Schoeni, J. L., and Wong, A. C. L. (1995) Enterotoxin activity of hemolysin BL from Bacillus cereus. Infect. Immun. 63, 4423-4428.

7. Doan, C. H. and Davidson, P. M. (1999) Growth of Bacillus cereus on oil-blanched potato strips for "home-style" French 
fries. J. Food Sci. 64, 909-912.

8. Garbeva, P., van Overbeek, L. S., van Vuurde, J. W. L., and van Elsas, J. D. (2001) Analysis of endophytic bacterial communities of potato by plating and denaturing gradient gel electrophoresis (DGGE) of 16S rDNA based PCR fragment. Microb. Ecol. 41, 369-383.

9. Granum, P. E. and Lund, T. (1997) Bacillus cereus and its food poisoning toxins. Microbiol. Lett. 157, 223-228.

10. Granum, P. E. (2002) Bacillus cereus and food poisoning. In: Applications and systematics of Bacillus and relatives. Berkeley R, Heyndrickx M, Logan N., and De Vos P. (eds) Blackwell Science Ltd., UK, pp. 37-46.

11. Häggblom, M. M., Apetroaie, C., Andersson, M. A., and Salkinoja-Salonenm, M. S. (2002) Quantitative analysis of cereulide, the emetic toxin of Bacillus cereus, produced under various conditions. Appl. Environ. Microbiol. 68, 2479-2483.

12. Heuer, H., Hartung, K., Wieland, G., Karmer, I., and Smalla, K. (1999) Polynucleotide probes that target a hypervariable region of $16 \mathrm{~S}$ rRNA genes to identify bacterial isolates corresponding to band of community fingerprints. Appl. Environ. Microbiol. 65, 1045-1049.

13. Johnson, K. M. (1984) Bacillus cereus foodborne illness: An update. J. Food Prot. 47, 145-153.

14. Larsen, H. D. and Jørgensen, K. (1999) Growth of Bacillus cereus in pasteurized milk products. Int. J. Food Microbiol. 46, 173-176.

15. Lund, B. M. (1990) Food-borne disease due to Bacillus and Clostridium species. Lancet 336, 982-986.

16. Nel, S., Lues, J. F. R., Buys, E. M., and Venter, P. (2004) Bacterial populations associated with meat from the deboning room of a high throughput red meat abattoir. Meat Sci. 66, 667-674.
17. Nortermans, S. and Batt, C.A. (1998) A risk assessment approach for food-borne Bacillus cereus and its toxins. $J$. Appl. Microbiol. 84, 51s-61s

18. Nortjé, G. L., Vorster, S. M., Greebe, R. P., and Steyn, P. L. (1999) Occurrence of Bacillus cereus and Yersinia enterocolitica in South African retail meats. Food Microbiol. 16, 213-217.

19. Nübel, U., Engelen, B., Felske, A., Snaidr, J., Wieshuber, A., Amann, R. I., Ludwig, W., and Backhaus, H. (1996) Sequence heterogeneities of genes encoding 16S rRNAs in Paenibacillus polymyxa detected by TGGE. J. Bacteriol. 178, 5636-5643.

20. Schoeni, J. L. and Wong, A. C. L. (2005) Bacillus cereus food poisoning and its toxins. J. Food Prot. 68, 636-648.

21. Shinagawa, K., Konuma, H., Tokumaru, M., Takemasa, N., Hashigiwa, M., Shigehisa, T., and Lopes, C. A. M. (1988) Enumeration of aerobic spore-formers and Bacillus cereus in meat product additives. J. Food Prot. 51, 648-650.

22. Sooltan, J. R. A., Mead, G. C., and Norris, A. P. (1987) Incidence and growth potential of Bacillus cereus in poultry meat products. Food Microbiol. 4, 347-351.

23. Toh, M., Moffitt, M. C., Henrichsen, L., Raftery, M., Barrow, K., Cox, J. M., Marquis, C. P., and Neilan, B. A. (2004) Cereulide, the emetic toxin of Bacillus cereus, is putatively a product of nonribosomal peptide synthesis. J. Appl. Microbiol. 97, 992-1000.

24. van Netten, P., van de Moosdijk, A., van Hoensel, P., Mossel, D. A. A., and Perales, I. (1990) Psychrotrophic strains of Bacillus cereus producing enterotoxin. J. Appl. Bacteriol. 69, 73-79

$\overline{\text { (Received 2010.7.26/Revised 2010.12.16/Accepted 2011.1.4) }}$ 